\title{
Evidence for a continuous decline in lower stratospheric ozone offsetting ozone layer recovery
}

\author{
William T. Ball ${ }^{1,2}$, Justin Alsing ${ }^{3,4}$, Daniel J. Mortlock ${ }^{4,5,6}$, Johannes Staehelin ${ }^{2}$, Joanna D. Haigh ${ }^{4,7}$, Thomas Peter $^{2}$, \\ Fiona Tummon ${ }^{2}$, Rene Stübi ${ }^{8}$, Andrea Stenke ${ }^{2}$, John Anderson ${ }^{9}$, Adam Bourassa ${ }^{10}$, Sean M. Davis ${ }^{11,12}$, \\ Doug Degenstein ${ }^{10}$, Stacey Frith ${ }^{13,14}$, Lucien Froidevaux ${ }^{15}$, Chris Roth ${ }^{10}$, Viktoria Sofieva ${ }^{16}$, Ray Wang ${ }^{17}$, \\ Jeannette Wild ${ }^{18,19}$, Pengfei Yu ${ }^{11,12}$, Jerald R. Ziemke ${ }^{13,20}$, and Eugene V. Rozanov ${ }^{1,2}$ \\ ${ }^{1}$ Physikalisch-Meteorologisches Observatorium Davos World Radiation Centre, Dorfstrasse 33, \\ 7260 Davos Dorf, Switzerland \\ ${ }^{2}$ Institute for Atmospheric and Climate Science, Swiss Federal Institute of Technology Zurich, \\ Universitaetstrasse 16, CHN, 8092 Zurich, Switzerland \\ ${ }^{3}$ Center for Computational Astrophysics, Flatiron Institute, 162 5th Ave, New York, NY 10010, USA \\ ${ }^{4}$ Physics Department, Blackett Laboratory, Imperial College London, SW7 2AZ, UK \\ ${ }^{5}$ Department of Mathematics, Imperial College London, SW7 2AZ, UK \\ ${ }^{6}$ Department of Astronomy, Stockholm University, 10691 Stockholm, Sweden \\ ${ }^{7}$ Grantham Institute - Climate Change and the Environment, Imperial College London, SW7 2AZ, UK \\ ${ }^{8}$ Federal Office of Meteorology and Climatology, MeteoSwiss, 1530 Payerne, Switzerland \\ ${ }^{9}$ School of Science, Hampton University, Hampton, VA, USA \\ ${ }^{10}$ Institute of Space and Atmospheric Studies, University of Saskatchewan, Saskatoon, Canada \\ ${ }^{11}$ Cooperative Institute for Research in Environmental Sciences, University of Colorado, Boulder, CO, USA \\ ${ }^{12}$ NOAA Earth System Research Laboratory, Boulder, CO, USA \\ ${ }^{13}$ NASA Goddard Space Flight Center, Greenbelt, MD, USA \\ ${ }^{14}$ Science Systems and Applications Inc., Lanham, MD, USA \\ ${ }^{15}$ Jet Propulsion Laboratory, California Institute of Technology, Pasadena, CA, USA \\ ${ }^{16}$ Finnish Meteorological Institute, Earth Observation, Helsinki, Finland \\ ${ }^{17}$ School of Earth and Atmospheric Sciences, Georgia Institute of Technology, Atlanta, GA, USA \\ ${ }^{18}$ NOAA/NWS/NCEP/Climate Prediction Center, College Park, MD, USA \\ ${ }^{19}$ Innovim LLC, Greenbelt, MD, USA \\ ${ }^{20}$ Morgan State University, Baltimore, Maryland, USA
}

Correspondence: William T. Ball (william.ball@env.ethz.ch)

Received: 13 September 2017 - Discussion started: 10 October 2017

Revised: 11 December 2017 - Accepted: 18 December 2017 - Published: 6 February 2018

\begin{abstract}
Ozone forms in the Earth's atmosphere from the photodissociation of molecular oxygen, primarily in the tropical stratosphere. It is then transported to the extratropics by the Brewer-Dobson circulation (BDC), forming a protective "ozone layer" around the globe. Human emissions of halogen-containing ozone-depleting substances (hODSs) led to a decline in stratospheric ozone until they were banned by the Montreal Protocol, and since 1998 ozone in the upper stratosphere is rising again, likely the recovery from halogen-
\end{abstract}

induced losses. Total column measurements of ozone between the Earth's surface and the top of the atmosphere indicate that the ozone layer has stopped declining across the globe, but no clear increase has been observed at latitudes between $60^{\circ} \mathrm{S}$ and $60^{\circ} \mathrm{N}$ outside the polar regions $\left(60-90^{\circ}\right)$. Here we report evidence from multiple satellite measurements that ozone in the lower stratosphere between $60^{\circ} \mathrm{S}$ and $60^{\circ} \mathrm{N}$ has indeed continued to decline since 1998 . We find that, even though upper stratospheric ozone is recover- 
ing, the continuing downward trend in the lower stratosphere prevails, resulting in a downward trend in stratospheric column ozone between $60^{\circ} \mathrm{S}$ and $60^{\circ} \mathrm{N}$. We find that total column ozone between $60^{\circ} \mathrm{S}$ and $60^{\circ} \mathrm{N}$ appears not to have decreased only because of increases in tropospheric column ozone that compensate for the stratospheric decreases. The reasons for the continued reduction of lower stratospheric ozone are not clear; models do not reproduce these trends, and thus the causes now urgently need to be established.

\section{Introduction}

The stratospheric ozone layer protects surface life from harmful solar ultraviolet radiation. In the second half of the 20th century, halogen-containing ozone-depleting substances (hODSs) resulting from human activity, mainly in the form of chlorofluorocarbons, led to the decline of the ozone layer (Molina and Rowland, 1974). The ozone hole over the South Pole was the clearest example of ozone depletion, but total column ozone was declining between $60^{\circ} \mathrm{S}$ and $60^{\circ} \mathrm{N}$ (Farman et al., 1985; WMO/NASA, 1988; WMO, 2011, 2014). The Montreal Protocol came into effect in 1989, banning multiple substances responsible for ozone layer depletion, and by the mid-2000s it had become apparent that a decline in total column ozone had stopped at almost all non-polar latitudes since around 1997 (WMO, 2007).

The general expectation is that global mean stratospheric column ozone will increase as hODSs continue to decline, but increasing total column ozone due to decreasing ODSs has not yet been reported (WMO, 2014); a cooling stratosphere is also thought to aid the recovery of ozone by slowing temperature-dependent reaction rates and by accelerating ozone transport through the meridional Brewer-Dobson circulation (BDC). Chemistry-climate models (CCMs) predict that mean total column ozone will increase, but this also remains uncertain since projections rely substantially on the $\mathrm{CO}_{2}, \mathrm{~N}_{2} \mathrm{O}$, and $\mathrm{CH}_{4}$ emissions scenarios (Revell et al., 2012; Nowack et al., 2015).

Only recently has a total column ozone recovery been detected over Antarctica during the austral spring (Solomon et al., 2016). However, non-polar $\left(<60^{\circ}\right)$ total column ozone levels have remained stable since 2000 (WMO, 2014), with most latitudes displaying a positive, but non-significant, decadal trend (WMO, 2014). Results from Frith et al. (2014) and Weber et al. (2017) suggest a potential peak in positive trends around 2011, after which positive trends decreased, and while uncertainties shrink, significance remains elusive.

Despite a lack of clear recovery in total column ozone, ozone appears to be significantly recovering in the upper stratosphere above $10 \mathrm{hPa}$ in multiple ozone composites that merge observations from various space missions, especially at mid-latitudes (Kyrölä et al., 2013; Laine et al., 2014; WMO, 2014; Tummon et al., 2015; Harris et al., 2015; Stein- brecht et al., 2017; Ball et al., 2017; Frith et al., 2017; Sofieva et al., 2017; Bourassa et al., 2017). Trends are almost always presented as percentage change per decade, which does not illuminate the contribution to the column ozone changes. Thus, a recovery in upper stratospheric ozone does not mean that stratospheric ozone as a whole is recovering. Indeed, if total column ozone does not display any significant changes since 1997, while the upper stratosphere displays significant increases, then either the uncertainties due to unattributed dynamical variability interfere in the significance of the trend determined through regression analysis, or there are counteracting trends at lower levels of the stratosphere or in the troposphere.

Suggestions of a decrease in lower stratospheric ozone have been presented elsewhere (Kyrölä et al., 2013; Gebhardt et al., 2014; Sioris et al., 2014; Nair et al., 2015; Vigouroux et al., 2015). However, it has been difficult to confirm (WMO, 2014; Harris et al., 2015; Steinbrecht et al., 2017) because (i) ozone is typically integrated over wide latitude bands and/or total column ozone is considered, both of which may lead to cancellation of opposing trends; (ii) large dynamical variability unaccounted for in regression analysis together with shorter time series lead to higher uncertainties (Tegtmeier et al., 2013); (iii) below $20 \mathrm{~km}$ there are large ozone gradients, with low ozone concentrations close to the tropopause; and (iv) composite-data merging techniques have hindered identification of robust changes (Harris et al., 2015; Ball et al., 2017).

In addition to only reporting decadal percentage changes, most studies typically do not consider altitudes below $20 \mathrm{~km}$ $(\sim 60 \mathrm{hPa})$, missing stratospheric changes down to $16 \mathrm{~km}$ in the tropics $\left(30^{\circ} \mathrm{S}-30^{\circ} \mathrm{N}\right)$ or $\sim 12 \mathrm{~km}$ at mid-latitudes $(60$ $30^{\circ}$ ), regions that contain a large fraction of, and drive most sub-decadal variability in, total column ozone. Absolute uncertainties between limb sounding instruments have been reported to be up to $\sim 10-15 \%$ near $16 \mathrm{~km}$ (Tegtmeier et al., 2013), which should be accounted for from bias corrections when composites are constructed, but which may also reduce confidence in variability and trends in the lower stratosphere. Nevertheless, a recent study by Bourassa et al. (2017) extended their analysis of the SAGE-II/OSIRIS ozone composite down to $18 \mathrm{~km}$, where widespread, partially significant, negative ozone trends (1998-2016) can be seen at all latitudes from $50^{\circ} \mathrm{S}$ to $50^{\circ} \mathrm{N}$. Models do predict a future decline in tropical lower stratospheric ozone (Eyring et al., 2010; WMO, 2011), but evidence for recent BDC-driven ozone decreases remain weak, and decreases identified at $32-36 \mathrm{~km}$ (near $10 \mathrm{hPa}$ ) are largely thought to be due to high ozone levels over 2000-2003 (WMO, 2014), and thus may be an artefact of the analysis period rather than a BDC change.

Finally, issues remain in the attribution and identification of ozone recovery usually performed through multiple linear regression (MLR) analysis that can lead to biased trend estimates (Damadeo et al., 2014; Ball et al., 2017) due to geolocation biases (Sofieva et al., 2014), vertical resolution 
(Kramarova et al., 2013), and satellite drifts and biases from merging data into composites (WMO, 2014; Tummon et al., 2015; Harris et al., 2015; Ball et al., 2017). Most studies consider either piecewise linear trends (PWLTs) or the equivalent effective stratospheric chlorine (EESC) proxy to represent the influence of hODSs on long-term ozone changes (Newman et al., 2007). Chehade et al. (2014) and Frith et al. (2014) both concluded that total column ozone trends up to 2012 and 2013 estimated from PWLTs or EESC prior to 1997 agree well, but post-1997 the EESC proxy implies significant and positive increases, while PWLTs are generally smaller and non-significant at most non-polar latitudes. This suggests that post-1997 changes in total column ozone may no longer be well represented by an EESC regressor. Since PWLT represents the overall trend without any specific physical attribution, the total column ozone may indeed be increasing at a slower rate than EESC estimates suggest, or not at all.

Here, we quantify the absolute changes in ozone in different regions of the stratosphere and troposphere and their contributions to total column ozone since 1998 at different latitudes and between $60^{\circ} \mathrm{S}$ and $60^{\circ} \mathrm{N}$ using a robust regression analysis approach (Sect. 2.1): dynamical linear modelling (DLM) (Laine et al., 2014; Ball et al., 2017). DLM provides a major step forward by estimating smoothly varying, non-linear background trends, without prescribing an EESC explanatory variable or restrictive piecewise linear assumptions. Although this precludes a clear physical attribution, similar to PWLT, it allows for an assessment of how ozone is evolving on decadal and longer timescales and to identify if and when an inflection in ozone occurs. We use updated ozone composites extended to 2015-2016 (Sect. 3) and put the DLM results of the longer time series in the context of previously reported percentage change trends, usually reported from $20 \mathrm{~km}$ upwards, but here extended down to the tropopause (Sect. 4.1). We then consider the absolute contribution to total column ozone of partial column ozone from the upper, middle, lower, and whole stratosphere (Sect. 4.2), and then the tropospheric contribution (Sect. 4.3). We finally show results from two CCMs in specified dynamics mode (Sect. 4.4), and in Sect. 5 we discuss our findings and conclude.

\section{Methods}

\subsection{Regression analysis}

The standard method to estimate decadal trends or changes in ozone, MLR, is known to have estimator bias and regressor aliasing (Marsh and Garcia, 2007; Chiodo et al., 2014). To minimise these effects we use a more robust method using a Bayesian inference approach through DLM (Laine et al., 2014; Ball et al., 2017; see Laine et al., 2014 for a detailed description of the DLM model and implementation). DLM is similar to MLR in that the same regressors (see Sect. 2.2, below) are used for known drivers of ozone variability, and an autoregressive term is included. However, the trend is not predetermined with a linear, or piecewise linear, model, but is allowed to smoothly vary in time, and the degree of trend non-linearity is an additional free parameter to be jointly inferred from the data. We infer posterior distributions on the non-linear trends by Markov chain Monte Carlo (MCMC) sampling; the background trend levels at every month are included as free parameters, with a data-driven prior on the smoothness of the month-to-month trend variability. DLM analyses have more principled uncertainties than MLR since they are based on a more flexible model and formally integrate over uncertainties in the regression coefficients, (nonstationary) seasonal cycle, autoregressive coefficients, and parameters characterising the degree of non-linearity in the trend. The time-varying background changes are inferred rather than specified by, for example, an estimate of EESC (Newman et al., 2007) or PWLT; there is no need for assumptions about when and where a decline in hODSs occurs.

\subsection{Regressor variables}

Similar to MLR, we use regressor time series that represent known drivers of stratospheric ozone variability. These include the $30 \mathrm{~cm}$ radio flux ( $F 30$ ) as a solar proxy (as it better represents UV variability than the commonly used $F 10.7 \mathrm{~cm}$ flux; Dudok de Wit et al., 2014), a latitudinally resolved stratospheric aerosol optical depth for volcanic eruptions (Thomason et al., 2017), an ENSO index (NCAR, 2013) representing El Niño-Southern Oscillation variability ${ }^{1}$, and the Quasi-Biennial Oscillation at 30 and $50 \mathrm{hPa}^{2}$. For total column ozone and partial column ozone trend estimates, we also use the Arctic and Antarctic Oscillation ${ }^{3}$ proxy for the Northern and Southern hemispheres. We use a second order autoregressive (AR2) process (Tiao et al., 1990) to avoid the autocorrelation of residuals. We remove the 2-year period following the Pinatubo eruption, i.e. June 1991 to May 1993, from the analysis to avoid problems related to impacts of satellite ozone retrieval due to stratospheric aerosol loading (Davis et al., 2016), and aliasing between regressors within the regression analysis (Chiodo et al., 2014; Kuchar et al., 2017); the volcanic aerosols still show slowly varying changes, which are important to consider as a regressor since volcanic aerosols have a larger impact on ozone in the lower stratosphere than the upper.

\footnotetext{
${ }^{1}$ From NOAA: http://www.esrl.noaa.gov/psd/enso/mei/table. html.

${ }^{2}$ From Freie Universität Berlin: http://www.geo.fu-berlin.de/en/ met/ag/strat/produkte/qbo/index.html.

${ }^{3}$ From http://www.cpc.ncep.noaa.gov/products/precip/CWlink/ daily_ao_index/teleconnections.shtml.
} 


\subsection{Statistics}

We do not apply any statistical tests and therefore avoid making assumptions about the (posterior) distributions. The posterior distributions that represent the change since January 1998 are formed from the $(n=100000)$ DLM samples from the MCMC exploration of the model parameters (see Sect. 2.1). Then, probability density functions (PDFs) are estimated as histograms of the sampled DLM changes from 1998. Finally, the probabilities represent the percentage of the posteriors that are negative; therefore, the posteriors and probabilities presented in all figures represent the full information about the change in ozone since 1998 obtained from the DLM analysis; these are not always normally distributed. Positive increases have values less than $50 \%$ and therefore increases at 80,90 , and $95 \%$ probabilities are indicated by their respective contours in Fig. 1 and have values less than or equal to 20, 10, and $5 \%$ in Fig. 2 (see also Figs. S1, S3, S4, S6, S9, and S10 in the Supplement).

\section{Ozone data}

\subsection{Satellite ozone composites}

A summary of the ozone merged datasets - SWOOSH (Davis et al., 2016), GOZCARDS (Froidevaux et al., 2015), SBUVMOD (Frith et al., 2017), SBUV-Merged-Cohesive (Wild and Long, 2018), SAGE-II/CCI/OMPS (Sofieva et al., 2017), and SAGE-II/OSIRIS/OMPS (Bourassa et al., 2014) - and an intercomparison of the publicly available data up to 2012 can be found in Tummon et al. (2015); data up to 2016 are available upon request from composite principal investigators (see also Steinbrecht et al., 2017). These data are monthly, zonally averaged, homogenised, and bias-corrected ozone datasets. Nevertheless, merged product uncertainties remain large in the upper troposphere and lower stratosphere (UTLS) region in merged products, with estimated monthly uncertainties of 3-9\% in SAGE-II-CCI-OMPS (Sofieva et al., 2017) and drifts of $\sim 1 \%$ per decade in the OSIRIS period of SAGE-IIOSIRIS-OMPS (Bourassa et al., 2017). Although data quality degrades in the UTLS, biases are still removed through the same procedure as other parts of the stratosphere and are thought to be performed optimally (Sofieva et al., 2014); results agree with studies focused on the tropical UTLS (Sioris et al., 2014). Additional uncertainties remain unquantified, such as those in the SBUV (vertically resolved) composites due to very low resolution in the lower stratosphere (Frith et al., 2017) and uncertainties that result from the unit conversion from number density to volume mixing ratio in the SWOOSH and GOZCARDS composites that require information about local temperature. We note, however, that formal definitions and calculations of uncertainties vary between composites and cannot necessarily be directly compared (Harris et al., 2015; Ball et al., 2017).
We consider the period 1985-2016 in all cases, except SAGE-II/CCI/OMPS up to 2015, as it ends in July 2016. We consider the latitudinal range $60^{\circ} \mathrm{S}$ to $60^{\circ} \mathrm{N}$ where all composites have latitudinal coverage and from 13 to $48 \mathrm{~km}$ in SAGE-II/CCI/OMPS and SAGE-II/OSIRIS/OMPS, the approximately equivalent pressure range of $147-1 \mathrm{hPa}$ that we consider in SWOOSH, GOZCARDS, and MergedSWOOSH/GOZCARDS; for SBUV-NOAA, SBUV-NASA, and Merged-SBUV we consider $50-1 \mathrm{hPa}$. SWOOSH, SBUV-Merged-Cohesive, and GOZCARDS have been updated since previous intercomparisons (Tummon et al., 2015; Harris et al., 2015); see Table 1 for more information. GOZCARDS v2.20, used here, includes SAGE-II v7.0 and has a finer vertical resolution than earlier versions. It must be stressed that the resolution of SBUV instruments below $25 \mathrm{~km}(22 \mathrm{hPa})$ is low (McPeters et al., 2013; Kramarova et al., 2013); thus, linear trends estimated at $25-46 \mathrm{hPa}$ also encompass altitudes lower than those that they formally represent (see Sect. 4 for a discussion on this).

\subsection{Merged-SWOOSH/GOZCARDS and Merged-SBUV}

SWOOSH and GOZCARDS are composites constructed with similar instrument data (Tummon et al., 2015; Ball et al., 2017) but with different preprocessing and merging techniques; the same is true for SBUV-MOD and SBUV-Merged-Cohesive, which are constructed using nadir-viewing backscatter instruments. The MergedSWOOSH/GOZCARDS and Merged-SBUV results presented here combine these two pairs of composites (Alsing and Ball, 2017), which show slightly different spatial variability (see Fig. S1) (Tummon et al., 2015; Harris et al., 2015; Steinbrecht et al., 2017; Frith et al., 2017). Part of the reason is related to offsets and drifts in the data that continue to be one of the largest remaining sources of uncertainty within, and between, ozone composites (Harris et al., 2015; Ball et al., 2017; Frith et al., 2017). These artefacts can be largely accounted for using the Bayesian integrated and consolidated (BASIC) methodology developed by Ball et al. (2017), which we apply to both pairs of data separately; examples of corrected time series in the lower stratosphere are given in Fig. S2, and others can be found in Ball et al. (2017). This method also fills data gaps, which is reasonable if they are discontinuous for only a few months. This is true for these datasets but is not for the SAGE-II/CCI/OMPS and SAGE-II/OSIRIS/OMPS.

\subsection{Total column ozone}

We use merged SBUV v8.6 (Frith et al., 2014) for comparison of results with total column ozone observations, which are available on a $5^{\circ}$ latitude grid from 1970 onwards. We verify the stability of SBUV total column ozone after 1997 by comparing SBUV total column ozone overpass data 
Table 1. List of datasets and coverage considered in this study; some data products cover ranges outside those quoted/used here. Data units are either Dobson units (DU), volume mixing ratio (vmr) in parts per million (ppm), or number density (n-den) in $\mathrm{cm}^{-3}$.

\begin{tabular}{|c|c|c|c|c|c|c|}
\hline Name & Region & Alt. or press. range & Location & Version & Units & Merged? \\
\hline SBUV-MOD $^{1}$ & Total column & $0-400 \mathrm{~km}$ & Space & v8.6 & DU & No \\
\hline Arosa $^{1}$ & Total column & $0-400 \mathrm{~km}$ & Ground & - & DU & No \\
\hline SBUV-MOD & Stratosphere & $50-1 \mathrm{hPa}$ & Space & $\mathrm{v} 8.6^{2}$ & vmr & $\mathrm{Yes}^{3}$ \\
\hline SBUV-Mer. Coh. & Stratosphere & $50-1 \mathrm{hPa}$ & Space & LOTUS $^{2}$ & vmr & $\mathrm{Yes}^{3}$ \\
\hline GOZCARDS & Stratosphere & $147-1 \mathrm{hPa}$ & Space & $\mathrm{v} 2.20^{2}$ & vmr & $\mathrm{Yes}^{4}$ \\
\hline SWOOSH & Stratosphere & $147-1 \mathrm{hPa}$ & Space & v2.6 & vmr & Yes $^{4}$ \\
\hline SAGE-II-OSIRIS-OMPS & Stratosphere & $13-48 \mathrm{~km}$ & Space & LOTUS $^{2}$ & n-den & No \\
\hline SAGE-II-CCI-OMPS ${ }^{1}$ & Stratosphere & $13-48 \mathrm{~km}$ & Space & Sofieva et al. (2017) & n-den & No \\
\hline OMI/MLS & Troposphere & $0-16 \mathrm{~km}$ & Space & $\mathrm{v} 9 / \mathrm{v} 4.2$ & DU & No \\
\hline WACCM-SD & All & $0-120 \mathrm{~km}$ & Model & $\mathrm{v} 4$ & $\mathrm{vmr}$ & No \\
\hline SOCOL-SD & All & $0-80 \mathrm{~km}$ & Model & v3 & vmr & No \\
\hline
\end{tabular}

1 All data consider the January 1985-December 2016 period, except SAGE-II-CCI-OMPS (1985-2015), Arosa (1970-2015), and SBUV-MOD total column ozone (1970-2016). ${ }^{2}$ All marked datasets were made available through the SPARC Long-term Ozone Trends and Uncertainties in the Stratosphere (LOTUS) activity; unmarked datasets are publicly available. ${ }^{3}$ SBUV-MOD and SBUV-Merged-Cohesive were merged to form Merged-SBUV using the BASIC algorithm laid out in Ball et al. (2017). ${ }^{4}$ GOZCARDS and SWOOSH were merged to form Merged-SWOOSH/GOZCARDS using the BASIC algorithm laid out in Ball et al. (2017).

with the independent Arosa ground measurements, which are available from 1926 to present (Scarnato et al., 2010).

\subsection{Tropospheric column ozone}

For tropospheric ozone, we consider Aura satellite Ozone Monitoring Instrument and Microwave Limb Sounder (OMI/MLS) tropospheric column ozone measurements, discussed by Ziemke et al. (2006). The tropospheric ozone is estimated through a residual method that derives daily maps of tropospheric column ozone by subtracting MLS stratospheric column ozone from co-located OMI total column ozone. The OMI/MLS data, including data quality and data description, are publicly available ${ }^{4}$. Coverage of the OMI/MLS ozone is monthly (October 2004-present) and at $1^{\circ} \times 1.25^{\circ}$ horizontal resolution, which we have zonally averaged to make comparisons here.

\section{Results}

\subsection{Post-1997 ozone changes resolved by latitude and altitude}

Concentrations of active stratospheric hODSs reached a maximum in $\sim 1997$ (Newman et al., 2007), and vertically resolved satellite measurements show evidence that upper stratospheric ozone $(10-1 \mathrm{hPa} ; \sim 32-48 \mathrm{~km})$ started recovering soon after (WMO, 2014). Figure 1 presents post-1998 ozone changes from four ozone composites that combine multiple satellite instruments (see Sect. 3). The

\footnotetext{
${ }^{4}$ From the NASA Goddard website https://acd-ext.gsfc.nasa. gov/Data_services/cloud_slice/.
}

Merged-SBUV and Merged-SWOOSH/GOZCARDS composites show $95 \%$ probability that upper stratospheric ozone at almost all latitudes between $60^{\circ} \mathrm{S}$ and $60^{\circ} \mathrm{N}$ has increased. This is less robust in SAGE-II/CCI/OMPS and SAGE-II/OSIRIS/OMPS, which show differences at equatorial latitudes $\left(10^{\circ} \mathrm{S}-10^{\circ} \mathrm{N}\right)$. The reason for the difference is not clear, but we note that in this region nearly $50 \%$ of the data are missing in the first 5 years (1998-2002), while Merged-SWOOSH/GOZCARDS and Merged-SBUV have no missing data (Harris et al., 2015).

In contrast to the upper stratosphere, all four composites show a consistent ozone decrease below $32 \mathrm{hPa}$ and $24 \mathrm{~km}$ at all latitudes (Fig. 1). The regions where probabilities are high (> 80, 90, and 95\%; see legend) are similar in all composites, except for Merged-SBUV, which has a lower vertical resolution. Right of Fig. 1a are two examples of the Merged-SBUV vertical resolution, indicating the contribution to ozone at a particular layer at tropical (solid) and northern mid-latitudes (dashed) (Kramarova et al., 2013). The profiles peaking at $3 \mathrm{hPa}$ (red) span $\sim 1-8 \mathrm{hPa}$ and contain only upper stratospheric changes. However, while changes at $25 \mathrm{hPa}$ (blue) show insignificant changes in the other higherresolution composites, the Merged-SBUV profile ranges between $\sim 15$ and $100 \mathrm{hPa}$, thus including the lowest part of the stratosphere where changes in the other composites are negative. We cannot use Merged-SBUV for comparison of resolved ozone changes, although a total column ozone product based upon these data can be used for comparison later (Sect. 4.3). While Merged-SBUV has a different spatial pattern, the increases in the upper, and decreases in the lower, stratosphere qualitatively agree with the other composites. 


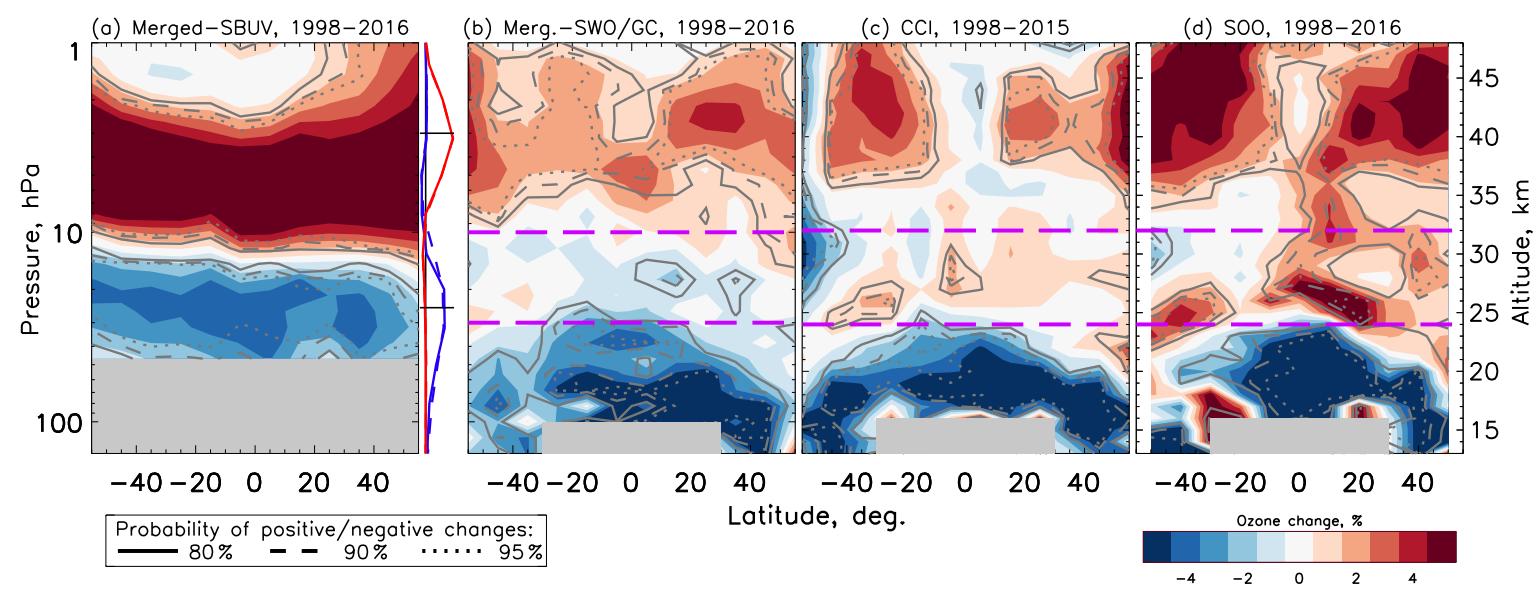

Figure 1. Zonally averaged change in ozone between 1998 and 2016. From (a-d) the Merged-SBUV, Merged-SWOOSH/GOZCARDS, SAGE-II/CCI/OMPS (CCI), and SAGE-II/OSIRIS/OMPS (SOO) composites. Red represents increases, blue decreases (\%; see right legend). Contours represent probability levels of positive or negative changes (see left legend). Grey shaded regions represent unavailable data. Pink dashed lines delimit regions integrated into partial ozone columns in Fig. 2 (and Figs. S3, S4, S6, S9, and S10). To the right of MergedSBUV are the instrument observing profiles centred at $3 \mathrm{hPa}$ (red, upper) and $25 \mathrm{hPa}$ (blue) at northern mid-latitudes (dashed) and in the tropics (solid) from Kramarova et al. (2013). SAGE-II/CCI/OMPS changes are for 1998-2015.

These results strongly indicate that ozone has declined in the lower stratosphere since 1998.

We note that our spatial results (Figs. 1 and $\mathrm{S} 1$ ) show similar patterns and changes to those presented in other studies, (e.g.WMO, 2014, Bourassa et al., 2014, Sofieva et al., 2017, Steinbrecht et al., 2017), though these typically do not extend below $20 \mathrm{~km}$ and thus often do not show the extensive decrease in lower stratospheric ozone that we do. Bourassa et al. (2017) extend down to $18 \mathrm{~km}$ and, indeed, show a larger region of decreasing ozone trends, but even this does not extend as far down as our results, i.e. $\sim 17 \mathrm{~km}$ for $30^{\circ} \mathrm{S}-30^{\circ} \mathrm{N}$ and $13 \mathrm{~km}$ outside this region. Our results do not qualitatively disagree with previous studies and approaches (WMO, 2014). However, 4 additional years of data (Tummon et al., 2015; Harris et al., 2015), an improved regression analysis method (Laine et al., 2014; Ball et al., 2017) (see Sect. 2), and techniques to account for data artefacts (Ball et al., 2017) increase our confidence in the identified changes in the lower stratosphere.

\subsection{Stratospheric and total column ozone post-1997 changes}

The spatial trends presented in Fig. 1 are informative for understanding where, and assessing why, changes in stratospheric ozone are occurring. However, stratospheric ozone changes are usually reported as decadal percentage change vertical profiles or spatial maps (e.g. as in Fig. 1), which hides the absolute changes in ozone and the contribution to the total column, which are almost never reported. A recovery in the upper stratosphere is important to identify, but this region contributes a smaller fraction to the total column than the middle and lower stratosphere. Thus, smaller percentage changes over a reduced altitude range in the lower stratosphere can actually produce larger integrated changes than in the more extended regions higher up.

In Fig. 2 we present changes in partial column ozone in Dobson units (DU) from Merged-SWOOSH/GOZCARDS for the whole stratospheric column and for the upper (10$1 \mathrm{hPa}$ ) and lower stratosphere $(147-32 \mathrm{hPa}$ or $13-24 \mathrm{~km}$ at $>30^{\circ} ; 100-32 \mathrm{hPa}$ or $17-24 \mathrm{~km}$ at $<30^{\circ}$ ). We note that the tropopause, the boundary layer between the troposphere and stratosphere, varies seasonally but is on average around $16 \mathrm{~km}$ (tropics) and 10-12 km (mid-latitudes); our conservative choice of slightly higher altitudes ensures that we avoid including the troposphere. Due to the near-complete temporal and vertical coverage, we focus on the Merged-SWOOSH/GOZCARDS composite (SAGEII/OSIRIS/OMPS and SAGE-II/CCI/OMPS are provided in Figs. S3 and S4, respectively ${ }^{5}$ ). Figure 2 shows posterior distributions of the 1998-2016 ozone changes, with black numbers representing the percentage of the distribution that is negative, in $10^{\circ}$ bands (left) and integrated into a "global" (defined as $60^{\circ} \mathrm{S}-60^{\circ} \mathrm{N}$ ) partial column ozone (right), along with the total column ozone observed by SBUV (red curves and numbers; upper row).

\footnotetext{
${ }^{5}$ It should be noted that while each latitude band partial column ozone of SAGE-II/OSIRIS/OMPS and SAGE-II/CCI/OMPS typically has between 60 and $90 \%$ of months where data are available for 1985-2015/2016, integrating bands across all latitudes leads to a reduction of available months (see Fig. S5), though estimates of the change since 1998 can still be made and uncertainties due to the reduced data are captured in the posteriors given in Figs. S3 and S4; this does not affect SBUV total column ozone or MergedSWOOSH/GOZCARDS.
} 

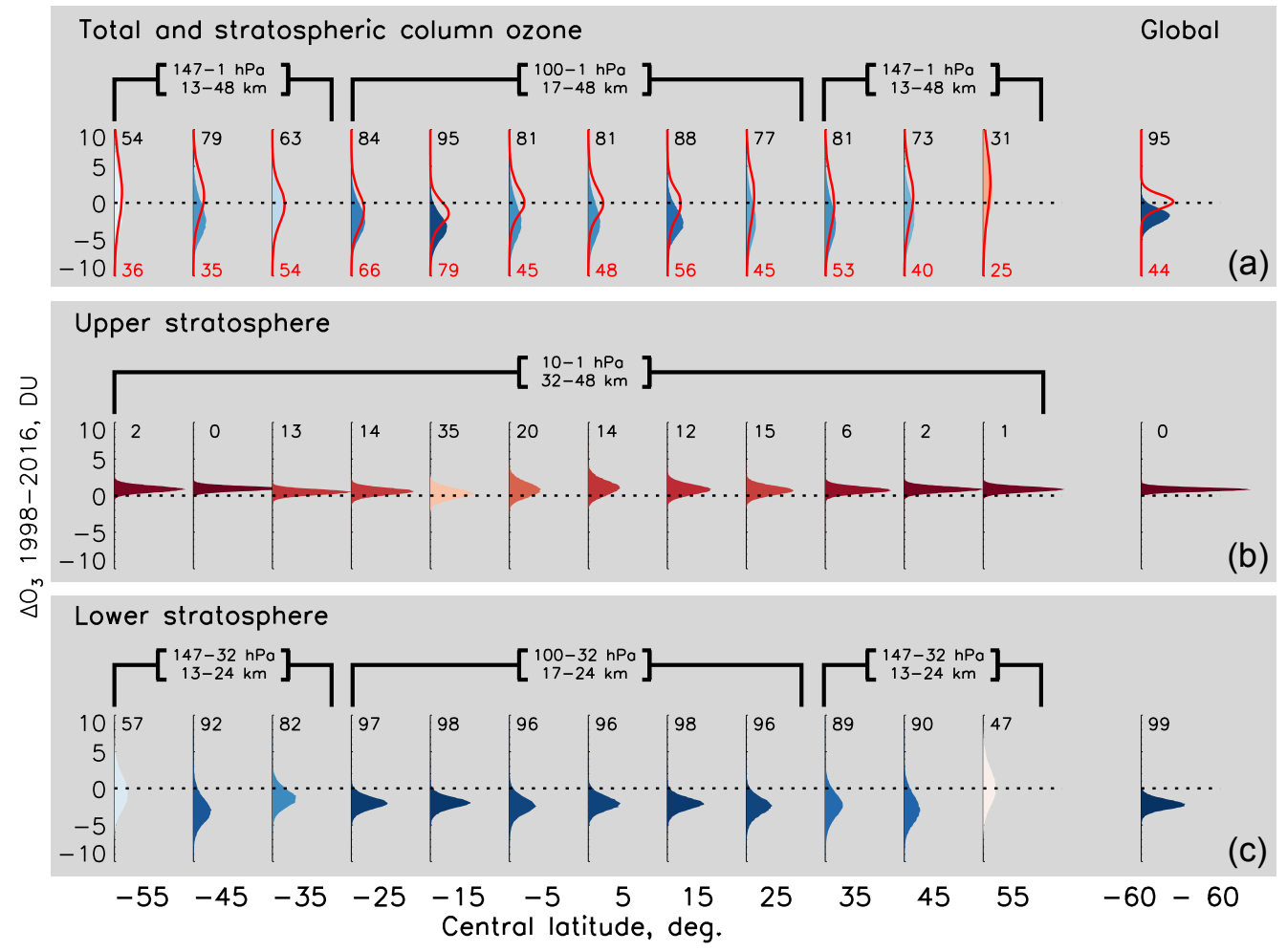

Figure 2. Merged-SWOOSH/GOZCARDS posterior distributions (shaded) for the 1998-2016 total and partial column ozone changes. (a) Whole stratospheric column and (b) upper and (c) lower stratosphere in $10^{\circ}$ bands for all latitudes (left) and integrated from $60^{\circ} \mathrm{S}$ to $60^{\circ} \mathrm{N}$ ("Global", right). The stratosphere extends deeper at mid-latitudes than equatorial latitudes (marked above each latitude). Numbers above each distribution represent the distribution percentage that is negative; colours are graded relative to the percentage distribution (positive, red-hues, with values $<50$; negative, blue). SBUV total column ozone (red curves) is given in the upper row and negative distribution percentages are given as red numbers.

Upper stratospheric ozone (Fig. 2, middle row) has increased since 1998 in almost all latitude bands, in half the cases at $>90 \%$ probability and $>95 \%$ at $40-60^{\circ}$ in both hemispheres. Integrated between $60^{\circ} \mathrm{S}$ and $60^{\circ} \mathrm{N}$, the probability exceeds $99 \%$ that upper stratospheric ozone has increased, confirming that the Montreal Protocol has indeed been successful in reversing trends in this altitude range.

Changes in the lower stratosphere (Fig. 2, lower row) show ozone decreases, typically exceeding $90 \%$ probability $\left(50^{\circ} \mathrm{S}-50^{\circ} \mathrm{N}\right)$. There is a $99 \%$ probability that lower stratospheric ozone integrated over $60^{\circ} \mathrm{S}-60^{\circ} \mathrm{N}$ has decreased since 1998; SAGE-II/OSIRIS/OMPS and SAGEII/CCI/OMPS both support this result with 87 and $99 \%$ probabilities, respectively (see Figs. S3 and S4).

Integrating the whole stratosphere vertically to form the stratospheric column ozone (Fig. 2, upper row), we see that all distributions imply a decrease (i.e. values $>50 \%$ ); probability is generally higher in tropical latitudes $\left(30^{\circ} \mathrm{S}-30^{\circ} \mathrm{N}\right)$. Integrating over all latitudes, stratospheric column ozone between $60^{\circ} \mathrm{S}$ and $60^{\circ} \mathrm{N}$ (right) indicates that stratospheric ozone has decreased with $95 \%$ probability. We compare the Merged-SWOOSH/GOZCARDS change with SBUV total column ozone (total column ozone posteriors shown as red lines in Fig. 2a), the latter of which includes both the troposphere and stratosphere. The SBUV total column ozone integrated over $60^{\circ} \mathrm{S}-60^{\circ} \mathrm{N}$ indicates that total column ozone has, in contrast to the stratospheric column ozone, changed little compared to 1998 .

We note that uncertainty remains in the middle stratosphere (see Fig. S6), with Merged-SWOOSH/GOZCARDS, SAGE-II/CCI/OMPS, and SAGE-II/OSIRIS/OMPS displaying different changes. SAGE-II/OSIRIS/OMPS, in particular, shows a significant positive trend, which leads to the $60^{\circ} \mathrm{S}-60^{\circ} \mathrm{N}$ integrated stratospheric column ozone indicating no change since 1998 (see Fig. S3). This is likely a result of how the data were merged to form composites (see examples in Fig. S7) at $30 \mathrm{~km}$ for northern mid-latitudes and $17 \mathrm{~km}$ for southern mid-latitudes, where steps and drifts can be seen in different composites and is an issue that remains to be resolved (Harris et al., 2015; Ball et al., 2017; Steinbrecht et al., 2017). Nevertheless, the changes in the upper and lower stratosphere are consistent in all ozone composites, and a latitudinally integrated stratospheric column ozone de- 


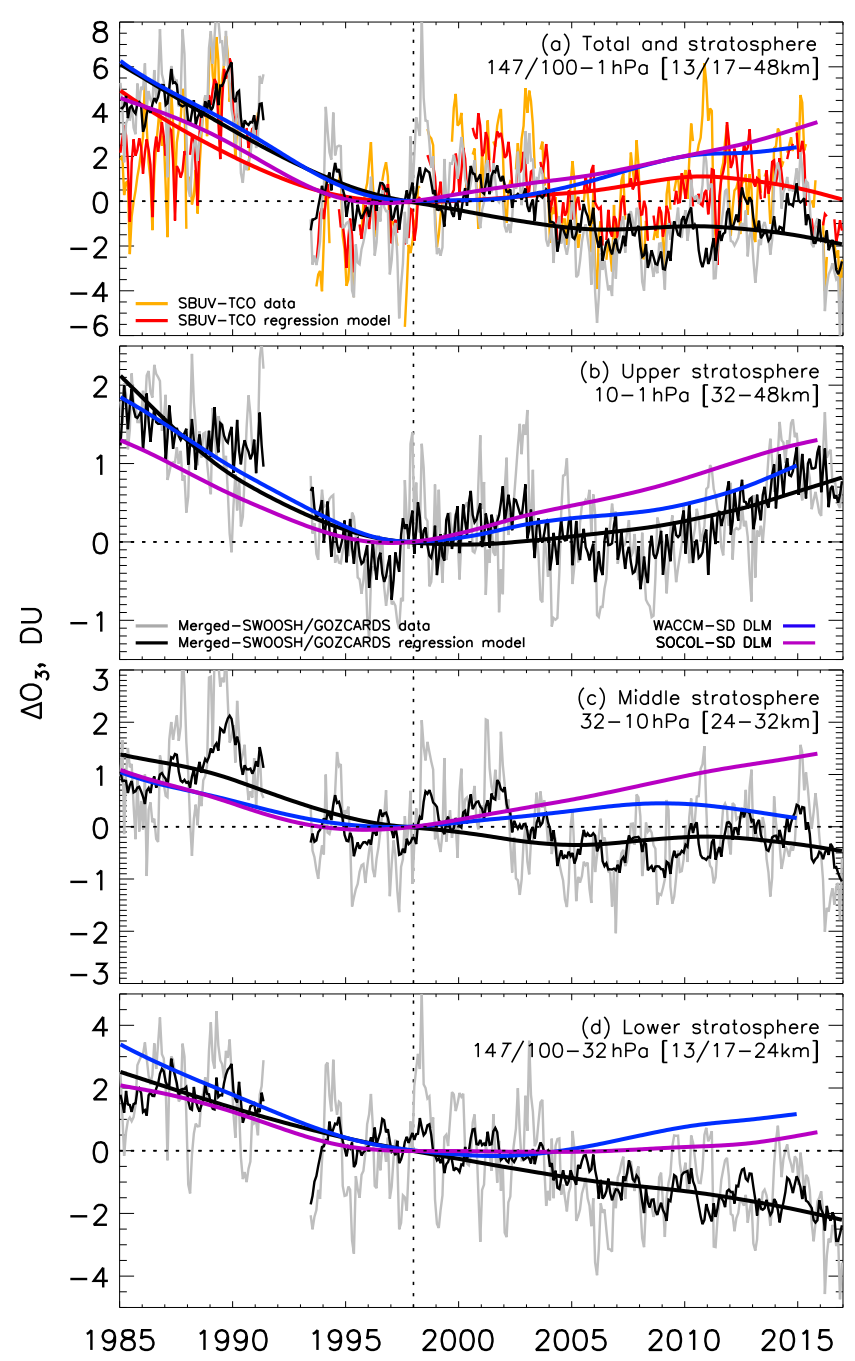

Figure 3. Total and partial column ozone anomalies integrated over $60^{\circ} \mathrm{S}-60^{\circ} \mathrm{N}$ between 1985 and 2016. Deseasonalised and regression model time series are given for the MergedSWOOSH/GOZCARDS composite (grey and black, respectively) for (a) the whole stratospheric column and (b) upper, (c) middle, and (d) lower stratospheric partial column ozone. The DLM nonlinear trend is the smoothly varying thick black line. In (a), the deseasonalised SBUV total column ozone is also given (orange), with the regression model (red) and the non-linear trend (thick, red). Data are shifted so that the trend line is zero in 1998. DLM results for WACCM-SD (blue) and SOCOL-SD (purple) from Fig. S11 are also shown; model results in (a) are for the stratospheric column.

cline is indicated by both Merged-SWOOSH/GOZCARDS and SAGE-II/CCI/OMPS.

To make these latitudinally integrated $\left(60^{\circ} \mathrm{S}-60^{\circ} \mathrm{N}\right)$ results clear, we show the SBUV total column ozone (orange and red represent deseasonalised time series and regression model fit, respectively) and MergedSWOOSH/GOZCARDS stratospheric column ozone (grey and black) in Fig. 3a; in all of the panels in Fig. 3, the time series are bias-shifted so that the smoothly varying nonlinear trend crosses the zero line in January 1998, so that relative changes can be clearly compared. It is interesting to note here that the SBUV total column ozone non-linear trend initially increases from 1998 and then peaks around 2011, before decreasing. Frith et al. (2014) and Weber et al. (2017) found similar behaviour when applying linear trend fits to SBUV total column ozone, fixing the start date in January 2000 and incrementally increasing the end date, i.e. the largest positive trend was found for the period 2000 2011 and thereafter trends decreased. Their analyses ended in 2013 and 2016, and the non-linear trend from our DLM analysis here shows identical behaviour and shows a continued decrease until 2016, which suggests that total column ozone has now returned to 1998 levels despite an initial upward trend. Qualitatively similar behaviour is seen in the Merged-SWOOSH/GOZCARDS stratospheric column ozone, though less pronounced because of its larger overall downward behaviour (see below, Sect. 4.3), which lends supporting, independent evidence that such a turnover in ozone trends might be real. The stratospheric column ozone from Merged-SWOOSH/GOZCARDS continued to decrease after 1998 and, while this decline stalled in the late 2000s, since 2012 it has continued to decrease. The overall result is that stratospheric column ozone is on average lower today than in 1998 by $\sim 1.9 \mathrm{DU}$.

The different stratospheric regimes that contribute to the stratospheric column ozone behaviour can be see in Fig. 3b-d, where we show upper, middle (10-32 hPa), and lower stratospheric ozone time series from MergedSWOOSH/GOZCARDS. A recovery is clear in the upper stratosphere in Fig. 3b, increasing by a mean of $\sim 0.8 \mathrm{DU}$, and trends have been relatively flat since 1998 in the middle stratosphere (Fig. 3c), with a mean decrease of $\sim 0.4 \mathrm{DU}$. However, the result from Merged-SWOOSH/GOZCARDS in the lower stratosphere (Fig. 3d) indicates not only that ozone there has declined by $\sim 2.2$ DU since 1998 , and has been the main contributor to the stratospheric column ozone decrease, but that the lower stratospheric ozone has seen a continuous and uninterrupted decrease. We note that a large proportion of the post-1997 decline occurred between 2003 and 2006, during which overlaps and switchovers between different combinations of instrument data were used to form the composites, most notably from the low-sampling SAGE-II instrument that ended operation in 2005; that said, all composites display similar behaviour, and overlaps and switchovers between different instrument data occur at different times (see Fig. 1 in both Tummon et al., 2015, and Sofieva et al., 2017).

\subsection{Tropospheric ozone contribution to total column ozone}

The stratosphere accounts for the majority $(\sim 90 \%)$ of total column ozone; thus, intuitively attribution to total column 


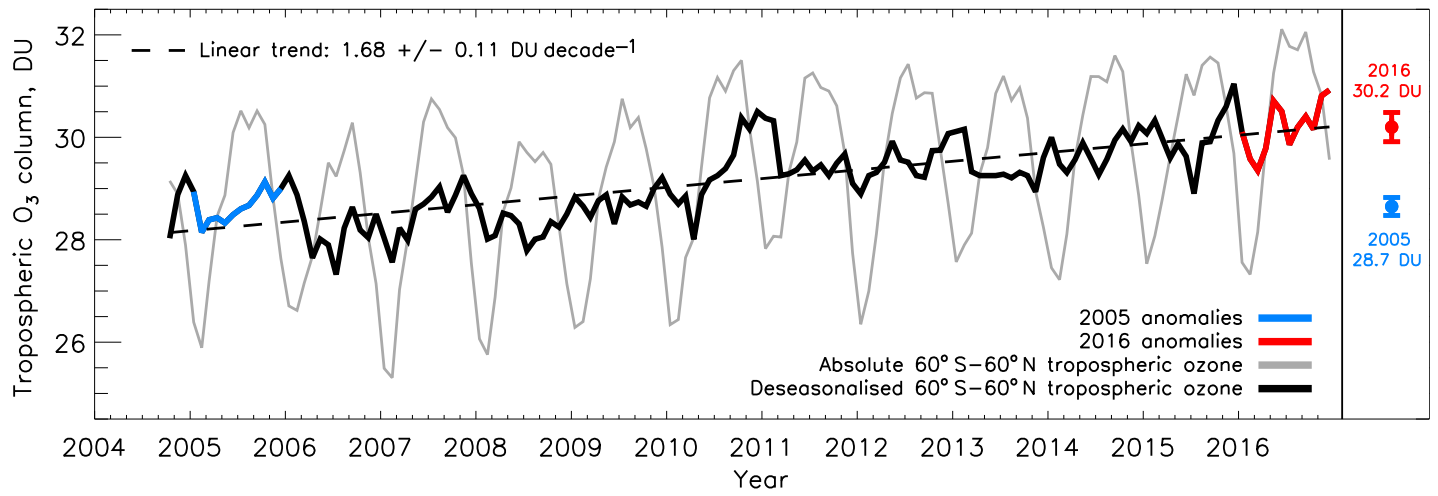

Figure 4. The $60^{\circ} \mathrm{S}-60^{\circ} \mathrm{N}$ total tropospheric column ozone between 2004 and 2016. OMI/MLS integrated ozone (grey line) and deseasonalised time series (black) are shown. The 2005 and 2016 periods are plotted in blue and red, respectively, and the mean and two standard errors on the mean for these two years are plotted on the right, with the mean value given alongside. The mean linear trend estimate (dashed line) and the 1 standard deviation uncertainty are also provided.

ozone changes would be expected to come primarily from this region. However, the results in Figs. 2 and 3 suggest a discrepancy between stratospheric column ozone and total column ozone. Despite this, there is no serious conflict between the different changes indicated by integrated $60^{\circ} \mathrm{S}-$ $60^{\circ} \mathrm{N}$ stratospheric column ozone and total column ozone distributions (Fig. 2a) and trends (Fig. 3a) when the remaining $10 \%$ of the total column ozone, i.e. tropospheric ozone, is considered, as we show in the following.

First, it is important to establish confidence in the SBUV total column ozone observations. These have been very stable since 1998 when comparing SBUV total column ozone overpass data to the independent ground-based Arosa total column ozone observations (see Fig. S8). This, therefore, provides confidence in the result that there is little net change in total column ozone since 1998. Additionally, Chehade et al. (2014) reported that other total column ozone composites agree very well with the SBUV total column ozone and there is little difference between the various total column ozone composites when performing trend analysis (see also Garane et al., 2017).

In a second step, we consider $60^{\circ} \mathrm{S}-60^{\circ} \mathrm{N}$ latitudinally integrated tropospheric ozone changes. In Fig. 4, we present recent estimates from OMI/MLS measurements $\left(60^{\circ} \mathrm{S}-60^{\circ} \mathrm{N}\right)$ of tropospheric column ozone from 2004 to 2016 (grey), along with deseasonalised anomalies (solid black); the deseasonalised years 2005 and 2016 are indicated in blue and red - the means (right) indicate a significant increase in ozone. A linear fit to the deseasonalised time series indicates an increase in tropospheric ozone of 1.68 DU per decade; if this has held true for the entire 19-year period (19982016) it implies a mean increase of $\sim 3 \mathrm{DU}$, which would more than account for the difference between the $60^{\circ} \mathrm{S}$ $60^{\circ} \mathrm{N}$ stratospheric column ozone and total column ozone peaks ( $\sim 2 \mathrm{DU})$ in the right of Fig. 2a.
Supporting evidence for tropospheric ozone increases comes from work reconstructing stratospheric ozone changes in a CCM. Shepherd et al. (2014) indicate that tropospheric ozone in the northern $\left(35^{\circ}-55^{\circ} \mathrm{N}\right)$ and southern midlatitudes $\left(35^{\circ}-55^{\circ} \mathrm{S}\right)$ ozone may have increased by $\sim 1 \mathrm{DU}$ $(1998-2011)$, while equatorial $\left(25^{\circ} \mathrm{S}-25^{\circ} \mathrm{N}\right)$ may have increased by $\sim 1.5 \mathrm{DU}$. While we consider a longer period, this qualitatively agrees with the latitude-resolved distributions in Fig. 2, which shows that all total column ozone posteriors indicate smaller probabilities of a decrease, or larger increases, compared to the Merged-SWOOSH/GOZCARDS stratospheric column ozone changes.

Returning to the OMI/MLS tropospheric column ozone, latitudinally resolved 2005-2015 changes show significant increases everywhere, except a non-significant increase at $50-60^{\circ} \mathrm{S}$ (see Fig S13). The latitudinal structure, with peaks at $\sim 30^{\circ}$ in both hemispheres and minima at southern equatorial and high latitudes, bears resemblance to the piecewise linear post-1998 total column ozone trends in Fig. 9 of Chehade et al. (2014) and Fig. 10 of Frith et al. (2014), although more detailed comparisons should be made. OMI/MLS results are not independent from MergedSWOOSH/GOZCARDS as Aura/MLS forms a part of this composite post-2005 but is independent from SBUV total column ozone. McPeters et al. (2015) state that OMI total column ozone is stable enough for trend studies, with a drift of less than $1 \%$ per decade compared to SBUV total column ozone and is one of the highest-quality ozone datasets. Ziemke and Cooper (2017) found no statistically significant drift with respect to independent measures or between MLS and OMI stratospheric column ozone residuals, although a small drift of +0.5 DU per decade was detected in OMI/MLS tropospheric column ozone caused by an error in the OMI total ozone, which was rectified for the version we consider here. 


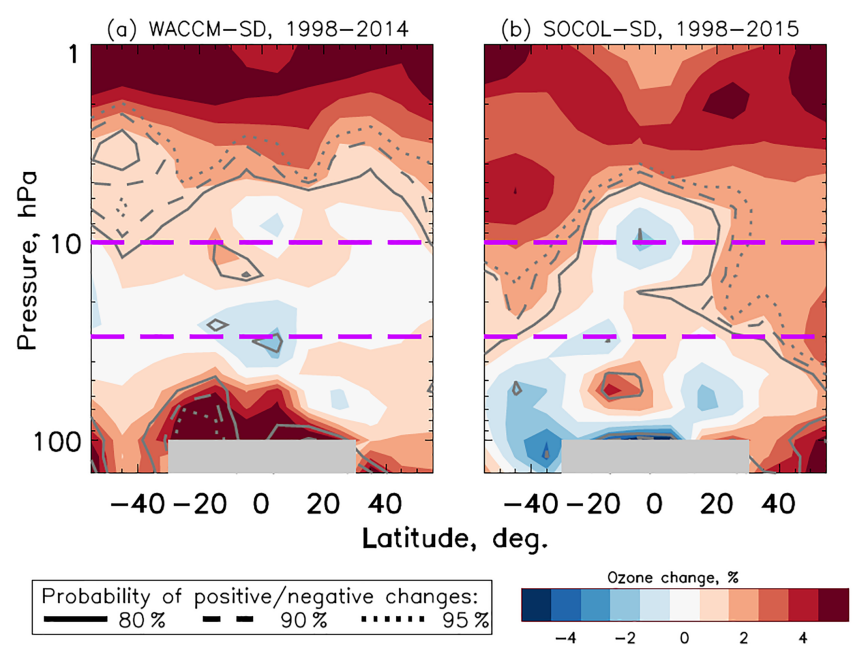

Figure 5. As for Fig. 1 but for (a) WACCM-SD and (b) SOCOLSD.

A deeper investigation is needed to understand the contributions of tropospheric column ozone and stratospheric column ozone to total column ozone, especially considering uncertainties carefully, but this is beyond the scope of this work. We note that studies using various data sources show less significant regional increases (and some decreases), with global estimates ranging from 0.2 to $0.7 \%$ per year $(\sim 0.6-2 \mathrm{DU}$ per decade) (Cooper et al., 2014; Ebojie et al., 2016; Heue et al., 2016), though these estimates considered different time periods. This suggests a large range of uncertainty, but even the lower end of the estimated increases in tropospheric column ozone are in line with the missing part of the total column ozone change, after considering stratospheric column ozone that we estimate here. Tropospheric ozone is not the main focus of the study here, but the evidence presented overall suggests that the missing component in the declining stratospheric column ozone distributions and trends, with respect to constant total column ozone, is indeed from increasing tropospheric ozone.

\subsection{Comparison of stratospheric spatial and partial column ozone trends with models}

The observational results for the lower, and whole, stratosphere presented thus far have not been previously reported. However, it is not clear that this represents a departure from our understanding of stratospheric trends as presented in modelling studies. We present the percentage ozone change from two state-of-the-art CCMs in Fig. 5: (a) the NCAR Community Earth System Model (CESM) Whole Atmosphere Community Climate Model-4 (WACCM; Marsh et al., 2013) and (b) the SOlar Climate Ozone Links (SOCOL; Stenke et al., 2013) model. Both simulations were performed with the Chemistry Climate Model Initiative phase 1 (CCMI1) boundary conditions in specified dynamics (SD) mode (see Morgenstern et al., 2017, for information on CCMI and boundary conditions used in models). SD uses reanalysis products to constrain model dynamics towards observations so as to best represent the dynamics of the atmosphere, while leaving chemistry to respond freely to these changes. Such an approach has proven highly accurate at reproducing ozone variability on monthly to decadal timescales in the equatorial upper stratosphere (Ball et al., 2016). WACCM-SD uses version 1 of the Modern-Era Retrospective Analysis for Research and Analysis (MERRA-1; Rienecker et al., 2011) reanalysis ${ }^{6}$, while SOCOL-SD uses ERA-Interim (Dee et al., 2011). Thus, the two models are both independent in terms of how they are constructed and the source of nudging fields used but have similar boundary conditions as prescribed by CCMI-1.

In Fig. 5 both models display broadly similar behaviour in the upper stratosphere above $10 \mathrm{hPa}$, roughly in line with the observations (Fig. 1). Spatially, in the middle stratosphere there are differences in sign, but generally significance is low: WACCM-SD displays broadly positive changes except in the tropics at 10 and $30 \mathrm{hPa}$, SOCOL-SD displays a negative spot centred in the tropics at $10 \mathrm{hPa}$, and mid-latitudes are often positive and significant. In the lower stratosphere, SOCOL-SD displays negative trends in the Southern Hemisphere lower stratosphere but positive trends in the Northern Hemisphere, while WACCM-SD is generally positive everywhere and significant at the lowest altitudes, except at $30-40 \mathrm{hPa}$ in the tropics where a negative tendency is seen. In both SOCOL-SD and WACCM-SD, trends in the lower stratosphere are generally not significant and do not display the clear and significant decreases found in the observations. Posterior distributions similar to those of Fig. 2 are presented for SOCOL-SD and WACCM-SD in Figs. S9 and S10, respectively. The displayed behaviour is spatially similar to that described here for the models in Fig. 5, and no significant decreases are found (two SOCOL-SD latitude bands display negative changes in the lower stratosphere with $\sim 75 \%$ probability: $30-40^{\circ} \mathrm{S}$ and $10-20^{\circ} \mathrm{N}$ ). It is worth noting that in both cases the integrated, $60^{\circ} \mathrm{S}-60^{\circ} \mathrm{N}$, trends in the stratospheric column ozone and upper stratosphere are all positive with probabilities of an increase exceeding $95 \%$ and positive in the lower stratosphere, with 69 and $85 \%$ probability of an increase in SOCOL-SD and WACCM-SD, respectively. The non-linear DLM trends (Fig. 3) of WACCMSD (blue) and SOCOL-SD (purple) emphasise the behaviour clearly differs from the observations, especially in the lower stratosphere (the deseasonalised and regression model time series are omitted from Fig. 3 for clarity but are provided

\footnotetext{
${ }^{6}$ Use of MERRA-2 reanalysis (Gelaro et al., 2017) makes little difference, except in the upper stratosphere after 2004, where positive trends are larger when using MERRA-2 (see Fig. S12). The WACCM-SD run with MERRA-2 uses CESM 1.2 .2 at $1.9 \times 2.5$ horizontal resolution and 88 vertical layers up to $140 \mathrm{~km}$, using prescribed aerosols from the RCP8.5 scenario.
} 
in Fig. S11). It is worth mentioning that the behaviour of stratospheric column ozone from the models was similar to SBUV total column ozone (Fig. 3a) until around 2012, after which modelled ozone continued to increase while observations show a gradual decline until 2016 (see discussion in Sect. 4.2).

The CCMVal-2 (SPARC, 2010) multi-model-mean 20002013 ozone changes in the WMO (2014) ozone assessment (chap. 2, Fig. 10) show a positive, but insignificant, change in the lower stratosphere at mid-latitudes, which suggests models may not be simulating that region correctly, consistent with the two models ending in 2014-2015. While CCMs capture historical ozone behaviour in the upper stratosphere well, it is less clear in the UTLS region. Fig. 7.27-7.28 of the SPARC (2010) report indicate large differences compared to observations in winter-spring, perhaps related to factors affecting model transport (e.g. resolution, and gravity wave parameterisations). Whether these differences result from model design, incorrect boundary conditions (e.g. underestimated anthropogenic (Yu et al., 2017) or volcanic (Bandoro et al., 2018) aerosol contributions), or missing chemistry remains an open question.

\section{Conclusions}

Following the successful implementation of the Montreal Protocol, total column ozone stabilised at the end of the 1990 s, but the search for the first signs of recovery in total column ozone integrated between $60^{\circ} \mathrm{S}$ and $60^{\circ} \mathrm{N}$ have not yet been successful (Weber et al., 2017; Chipperfield et al., 2017). The lower stratosphere, below $24 \mathrm{~km}$ ( $32 \mathrm{hPa})$, contains a large fraction of the total column ozone and is a region of large natural variability that has previously inhibited detection of significant trends (Weatherhead and Andersen, 2006). With longer time series, improved composites, and integration of the lower stratospheric column, we can now detect statistically significant trends in this region. We find that the negative ozone trend within the lower stratosphere between 1998 and 2016 is the main reason why a statistically significant recovery in total column ozone has remained elusive. Our main findings are as follows:

i. We further confirm other studies that the Montreal Protocol is successfully reducing the impact of halogenated ozone-depleting substances as indicated by the highly probable recovery $(>95 \%)$ measured in upper stratospheric regions $(1-10 \mathrm{hPa}$ or $32-48 \mathrm{~km})$.

ii. Lower stratospheric ozone (between 147 and $32 \mathrm{hPa}$ $(13-24 \mathrm{~km})$ at mid-latitudes, or 100 and $32 \mathrm{hPa}(17-$ $24 \mathrm{~km}$ ) at tropical latitudes) has continued to decrease since 1998 between $60^{\circ} \mathrm{S}$ and $60^{\circ} \mathrm{N}$, with a probability of $99 \%$ in two of the three analysed datasets and $87 \%$ in the third. iii. The main stratospheric dataset considered indicates a highly probable $(95 \%)$ decrease in the ozone layer since 1998 , i.e. in stratospheric ozone (between 147 and $1 \mathrm{hPa}$ $(13-48 \mathrm{~km})$ at mid-latitudes, or 100 and $1 \mathrm{hPa}$ (17$48 \mathrm{~km})$ at tropical latitudes) integrated over latitudes $60^{\circ} \mathrm{S}-60^{\circ} \mathrm{N}-$ the other composites support this result when considering the associated caveats of each.

iv. There is no significant change in total column ozone between 1998 and 2016, which includes both tropospheric ozone and the stratospheric ozone layer - indeed no change is the most probable result indicated, which our findings imply is a consequence of increasing tropospheric ozone, together with the slowed rate of decrease in stratospheric ozone following the Montreal Protocol.

v. State-of-the-art models, nudged to have historical atmospheric dynamics as realistic as possible, do not reproduce these observed decreases in lower stratospheric ozone.

We posit several possible explanations for the continuing decline in lower stratospheric ozone, beginning with those related to dynamics. First, part of the tropical and subtropical $\left(<30^{\circ}\right)$ lower stratospheric decline may be linked to a greenhouse-gas-related BDC acceleration (Randel and $\mathrm{Wu}$, 2007; Oman et al., 2010; WMO, 2014) indicated from CCM simulations, although observational evidence remains weak, and a faster BDC in general would slow ozone destruction cycles and hence mid-latitude ozone would increase and overcompensate for the tropical ozone reduction (WMO, 2014). Second, a rise in the tropopause (Santer et al., 2003), due to the warming troposphere, could lead to a decrease in ozone at mid-latitudes (Steinbrecht et al., 1998; Varotsos et al., 2004), but the tropopause rise is also affected by the ozone loss itself (Son et al., 2009), rendering its attribution difficult. Third, here we hypothesise a so-far-notdiscussed mechanism: an acceleration of the lower stratosphere BDC shallow branch (Randel and Wu, 2007; Oman et al., 2010) might increase transport of ozone-poor air to the mid-latitudes from the tropical lower stratosphere (Johnston, 1975; Perliski et al., 1989). The quality of the applied dynamical fields in the specified dynamics models considered in this study, or the way models handle transport in the lower stratosphere (SPARC, 2010; Dietmüller et al., 2017), may be dynamically related reasons why models do not reproduce the observed lower stratospheric ozone changes.

While dynamically driven explanations may be fully responsible for tropical lower stratospheric ozone changes, at mid-latitudes additional chemically driven contributions from increasing anthropogenic and natural very-short-lived substances (VSLSs) containing chlorine or bromine may play a role (Hossaini et al., 2015). Modelling studies imply that VSLSs preferentially destroy lower stratospheric ozone, though the effect outside of the polar latitudes is expected to be small (Hossaini et al., 2015, 2017). While VSLSs are 
thought to delay the recovery of the ozone layer, much uncertainty remains since observations and reaction rate kinetics are only available for some VSLSs (Oram et al., 2017). The uncertainties in model chemical boundary conditions, e.g. the prescribed emissions of VSLSs, therefore, may also be a reason why models do not reproduce the trends we report here.

The Montreal Protocol is working, but if the negative trend in lower stratospheric ozone persists, its efficiency might be disputed. Restoration of the ozone layer is essential to reduce the harmful effects of solar UV radiation (WMO, 2014) that impact human and ecosystem health (Slaper et al., 1996). Presently, models do not robustly reproduce the decline in lower stratospheric ozone identified here. This will be imperative, both to predict future changes and to determine if it is possible to prevent further decreases.

Data availability. Merged-SWOOSH/GOZCARDS and Merged-

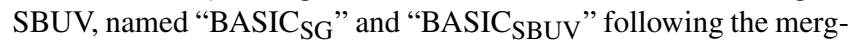
ing method used from Ball et al. (2017), are available for download from https://data.mendeley.com/datasets/2mgx2xzzpk/2 (Alsing and Ball, 2017).

\section{The Supplement related to this article is available online at https://doi.org/10.5194/acp-18-1379-2018-supplement.}

Competing interests. The authors declare that they have no conflict of interest.

Acknowledgements. William T. Ball and Eugene V. Rozanov were funded by the SNSF project 163206 (SIMA). We thank the SPARC LOTUS working group for discussion and data exchange. Work at the Jet Propulsion Laboratory was performed under contract with the National Aeronautics and Space Administration. GOZCARDS ozone data contributions from Ryan Fuller (at JPL) are gratefully acknowledged. We are grateful to Daniel Marsh and Doug Kinnison for providing ozone data from WACCM CESM in specified dynamics mode.

Edited by: Marc von Hobe

Reviewed by: two anonymous referees

\section{References}

Alsing, J. and Ball, W. T.: BASIC-SG (Merged-SWOOSHGOZCARDS) for "Evidence for a continuous decline in lower stratospheric ozone offsetting ozone layer recovery", https://doi.org/10.17632/2mgx2xzzpk.1, 2017.

Ball, W. T., Haigh, J. D., Rozanov, E. V., Kuchar, A., Sukhodolov, T., Tummon, F., Shapiro, A. V., and Schmutz,
W.: High solar cycle spectral variations inconsistent with stratospheric ozone observations, Nat. Geosci., 9, 206-209, https://doi.org/10.1038/ngeo2640, 2016.

Ball, W. T., Alsing, J., Mortlock, D. J., Rozanov, E. V., Tummon, F., and Haigh, J. D.: Reconciling differences in stratospheric ozone composites, Atmos. Chem. Phys., 17, 1226912302, https://doi.org/10.5194/acp-17-12269-2017, 2017.

Bandoro, J., Solomon, S., Santer, B. D., Kinnison, D. E., and Mills, M. J.: Detectability of the impacts of ozone-depleting substances and greenhouse gases upon stratospheric ozone accounting for nonlinearities in historical forcings, Atmos. Chem. Phys., 18, 143-166, https://doi.org/10.5194/acp-18-143-2018, 2018.

Bourassa, A. E., Degenstein, D. A., Randel, W. J., Zawodny, J. M., Kyrölä, E., McLinden, C. A., Sioris, C. E., and Roth, C. Z.: Trends in stratospheric ozone derived from merged SAGE II and Odin-OSIRIS satellite observations, Atmos. Chem. Phys., 14, 6983-6994, https://doi.org/10.5194/acp-14-6983-2014, 2014.

Bourassa, A. E., Roth, C. Z., Zawada, D. J., Rieger, L. A., McLinden, C. A., and Degenstein, D. A.: Drift corrected Odin-OSIRIS ozone product: algorithm and updated stratospheric ozone trends, Atmos. Meas. Tech. Discuss., https://doi.org/10.5194/amt-2017229, in review, 2017.

Chehade, W., Weber, M., and Burrows, J. P.: Total ozone trends and variability during 1979-2012 from merged data sets of various satellites, Atmos. Chem. Phys., 14, 7059-7074, https://doi.org/10.5194/acp-14-7059-2014, 2014.

Chiodo, G., Marsh, D. R., Garcia-Herrera, R., Calvo, N., and García, J. A.: On the detection of the solar signal in the tropical stratosphere, Atmos. Chem. Phys., 14, 5251-5269, https://doi.org/10.5194/acp-14-5251-2014, 2014.

Chipperfield, M. P., Bekki, S., Dhomse, S., Harris, N. R. P., Hassler, B., Hossaini, R., Steinbrecht, W., Thiéblemont, R., and Weber, M.: Detecting recovery of the stratospheric ozone layer, Nature, 549, 211-218, https://doi.org/10.1038/nature23681, 2017.

Cooper, O. R., Parrish, D. D., Ziemke, J., Balashov, N. V., Cupeiro, M., Galbally, I. E., Gilge, S., Horowitz, L., Jensen, N. R., Lamarque, J.-F., Naik, V., Oltmans, S. J., J., S., T., S. D., Thompson, A. M., Thouret, V., Wang, Y., and Zbinden, R. M.: Global distribution and trends of tropospheric ozone: An observation-based review, Elem Sci Anth., p. 29, https://doi.org/10.12952/journal.elementa.000029, 2014.

Damadeo, R. P., Zawodny, J. M., and Thomason, L. W.: Reevaluation of stratospheric ozone trends from SAGE II data using a simultaneous temporal and spatial analysis, Atmos. Chem. Phys., 14, 13455-13470, https://doi.org/10.5194/acp-14-134552014, 2014.

Davis, S. M., Rosenlof, K. H., Hassler, B., Hurst, D. F., Read, W. G., Vömel, H., Selkirk, H., Fujiwara, M., and Damadeo, R.: The Stratospheric Water and Ozone Satellite Homogenized (SWOOSH) database: a long-term database for climate studies, Earth Syst. Sci. Data, 8, 461-490, https://doi.org/10.5194/essd8-461-2016, 2016.

Dee, D. P., Uppala, S. M., Simmons, A. J., Berrisford, P., Poli, P., Kobayashi, S., Andrae, U., Balmaseda, M. A., Balsamo, G., Bauer, P., Bechtold, P., Beljaars, A. C. M., van de Berg, L., Bidlot, J., Bormann, N., Delsol, C., Dragani, R., Fuentes, M., Geer, A. J., Haimberger, L., Healy, S. B., Hersbach, H., Hólm, E. V., Isaksen, L., Kållberg, P., Köhler, M., Matricardi, M., McNally, A. P., Monge-Sanz, B. M., Morcrette, J.-J., Park, B.-K., Peubey, 
C., de Rosnay, P., Tavolato, C., Thépaut, J.-N., and Vitart, F.: The ERA-Interim reanalysis: configuration and performance of the data assimilation system, Q. J. Roy. Meteor. Soc., 137, 553-597, https://doi.org/10.1002/qj.828, 2011.

Dietmüller, S., Garny, H., Plöger, F., Jöckel, P., and Cai, D.: Effects of mixing on resolved and unresolved scales on stratospheric age of air, Atmos. Chem. Phys., 17, 7703-7719, https://doi.org/10.5194/acp-17-7703-2017, 2017.

Dudok de Wit, T., Bruinsma, S., and Shibasaki, K.: Synoptic radio observations as proxies for upper atmosphere modelling, J. Space Weather Spac., 4, A06, https://doi.org/10.1051/swsc/2014003, 2014.

Ebojie, F., Burrows, J. P., Gebhardt, C., Ladstätter-Weißenmayer, A., von Savigny, C., Rozanov, A., Weber, M., and Bovensmann, H.: Global tropospheric ozone variations from 2003 to 2011 as seen by SCIAMACHY, Atmos. Chem. Phys., 16, 417-436, https://doi.org/10.5194/acp-16-417-2016, 2016.

Eyring, V., Cionni, I., Bodeker, G. E., Charlton-Perez, A. J., Kinnison, D. E., Scinocca, J. F., Waugh, D. W., Akiyoshi, H., Bekki, S., Chipperfield, M. P., Dameris, M., Dhomse, S., Frith, S. M., Garny, H., Gettelman, A., Kubin, A., Langematz, U., Mancini, E., Marchand, M., Nakamura, T., Oman, L. D., Pawson, S., Pitari, G., Plummer, D. A., Rozanov, E., Shepherd, T. G., Shibata, K., Tian, W., Braesicke, P., Hardiman, S. C., Lamarque, J. F., Morgenstern, O., Pyle, J. A., Smale, D., and Yamashita, Y.: Multimodel assessment of stratospheric ozone return dates and ozone recovery in CCMVal-2 models, Atmos. Chem. Phys., 10, 94519472, https://doi.org/10.5194/acp-10-9451-2010, 2010.

Farman, J. C., Gardiner, B. G., and Shanklin, J. D.: Large losses of total ozone in Antarctica reveal seasonal $\mathrm{ClO}_{x} / \mathrm{NO}_{x}$ interaction, Nature, 315, 207-210, https://doi.org/10.1038/315207a0, 1985.

Frith, S. M., Kramarova, N. A., Stolarski, R. S., McPeters, R. D., Bhartia, P. K., and Labow, G. J.: Recent changes in total column ozone based on the SBUV Version 8.6 Merged Ozone Data Set, J. Geophy. Res.-Atmos., 119, 9735-9751, https://doi.org/10.1002/2014JD021889, 2014.

Frith, S. M., Stolarski, R. S., Kramarova, N. A., and McPeters, R. D.: Estimating uncertainties in the SBUV Version 8.6 merged profile ozone data set, Atmos. Chem. Phys., 17, 14695-14707, https://doi.org/10.5194/acp-17-14695-2017, 2017.

Froidevaux, L., Anderson, J., Wang, H.-J., Fuller, R. A., Schwartz, M. J., Santee, M. L., Livesey, N. J., Pumphrey, H. C., Bernath, P. F., Russell III, J. M., and McCormick, M. P.: Global OZone Chemistry And Related trace gas Data records for the Stratosphere (GOZCARDS): methodology and sample results with a focus on $\mathrm{HCl}, \mathrm{H}_{2} \mathrm{O}$, and $\mathrm{O}_{3}$, Atmos. Chem. Phys., 15, 1047110507, https://doi.org/10.5194/acp-15-10471-2015, 2015.

Garane, K., Lerot, C., Coldewey-Egbers, M., Verhoelst, T., Zyrichidou, I., Balis, D. S., Danckaert, T., Goutail, F., Granville, J., Hubert, D., Koukouli, M. E., Keppens, A., Lambert, J.-C., Loyola, D., Pommereau, J.-P., Van Roozendael, M., and Zehner, C.: Quality assessment of the Ozone_cci Climate Research Data Package (release 2017): 1. Ground-based validation of total ozone column data products, Atmos. Meas. Tech. Discuss., https://doi.org/10.5194/amt-2017-378, in review, 2017.

Gebhardt, C., Rozanov, A., Hommel, R., Weber, M., Bovensmann, H., Burrows, J. P., Degenstein, D., Froidevaux, L., and Thompson, A. M.: Stratospheric ozone trends and variability as seen by SCIAMACHY from 2002 to 2012, Atmos. Chem. Phys., 14 831-846, https://doi.org/10.5194/acp-14-831-2014, 2014.

Gelaro, R., McCarty, W., Suárez, M. J., Todling, R., Molod, A., Takacs, L., Randles, C. A., Darmenov, A., Bosilovich, M. G., Reichle, R., Wargan, K., Coy, L., Cullather, R., Draper, C., Akella, S., Buchard, V., Conaty, A., da Silva, A. M., Gu, W., Kim, G.K., Koster, R., Lucchesi, R., Merkova, D., Nielsen, J. E., Partyka, G., Pawson, S., Putman, W., Rienecker, M., Schubert, S. D., Sienkiewicz, M., and Zhao, B.: The Modern-Era Retrospective Analysis for Research and Applications, Version 2 (MERRA-2), J. Climate, 30, 5419-5454, https://doi.org/10.1175/JCLI-D-160758.1, 2017.

Harris, N. R. P., Hassler, B., Tummon, F., Bodeker, G. E., Hubert, D., Petropavlovskikh, I., Steinbrecht, W., Anderson, J., Bhartia, P. K., Boone, C. D., Bourassa, A., Davis, S. M., Degenstein, D., Delcloo, A., Frith, S. M., Froidevaux, L., Godin-Beekmann, S., Jones, N., Kurylo, M. J., Kyrölä, E., Laine, M., Leblanc, S. T., Lambert, J.-C., Liley, B., Mahieu, E., Maycock, A., de Mazière, M., Parrish, A., Querel, R., Rosenlof, K. H., Roth, C., Sioris, C., Staehelin, J., Stolarski, R. S., Stübi, R., Tamminen, J., Vigouroux, C., Walker, K. A., Wang, H. J., Wild, J., and Zawodny, J. M.: Past changes in the vertical distribution of ozone - Part 3: Analysis and interpretation of trends, Atmos. Chem. Phys., 15, 9965-9982, https://doi.org/10.5194/acp15-9965-2015, 2015.

Heue, K.-P., Coldewey-Egbers, M., Delcloo, A., Lerot, C., Loyola, D., Valks, P., and van Roozendael, M.: Trends of tropical tropospheric ozone from 20 years of European satellite measurements and perspectives for the Sentinel-5 Precursor, Atmos. Meas. Tech., 9, 5037-5051, https://doi.org/10.5194/amt-9-50372016, 2016.

Hossaini, R., Chipperfield, M. P., Montzka, S. A., Rap, A., Dhomse, S., and Feng, W.: Efficiency of short-lived halogens at influencing climate through depletion of stratospheric ozone, Nat. Geosci., 8, 186-190, https://doi.org/10.1038/ngeo2363, 2015.

Hossaini, R., Chipperfield, M. P., Montzka, S. A., Leeson, A. A., Dhomse, S., and Pyle, J. A.: The increasing threat to stratospheric ozone from dichloromethane, Nat. Commun., 8, 15962, https://doi.org/10.1038/ncomms15962, 2017.

Johnston, H. S.: Global ozone balance in the natural stratosphere, Rev. Geophys. Space Ge., 13, 637-649, https://doi.org/10.1029/RG013i005p00637, 1975.

Kramarova, N. A., Bhartia, P. K., Frith, S. M., McPeters, R. D., and Stolarski, R. S.: Interpreting SBUV smoothing errors: an example using the quasi-biennial oscillation, Atmos. Meas. Tech., 6, 2089-2099, https://doi.org/10.5194/amt-6-2089-2013, 2013.

Kuchar, A., Ball, W. T., Rozanov, E. V., Stenke, A., Revell, L., Miksovsky, J., Pisoft, P., and Peter, T.: On the aliasing of the solar cycle in the lower stratospheric tropical temperature, J. Geophys. Res.-Atmos., 122, 9076-9093, https://doi.org/10.1002/2017JD026948, 2017.

Kyrölä, E., Laine, M., Sofieva, V., Tamminen, J., Päivärinta, S.M., Tukiainen, S., Zawodny, J., and Thomason, L.: Combined SAGE II-GOMOS ozone profile data set for 1984-2011 and trend analysis of the vertical distribution of ozone, Atmos. Chem. Phys., 13, 10645-10658, https://doi.org/10.5194/acp-13-106452013, 2013.

Laine, M., Latva-Pukkila, N., and Kyrölä, E.: Analysing timevarying trends in stratospheric ozone time series using the 
state space approach, Atmos. Chem. Phys., 14, 9707-9725, https://doi.org/10.5194/acp-14-9707-2014, 2014.

Marsh, D. R. and Garcia, R. R.: Attribution of decadal variability in lower-stratospheric tropical ozone, Geophys. Res. Lett., 34, L21807, https://doi.org/10.1029/2007GL030935, 2007.

Marsh, D. R., Mills, M. J., Kinnison, D. E., Lamarque, J.-F., Calvo, N., and Polvani, L. M.: Climate Change from 1850 to 2005 Simulated in CESM1(WACCM), J. Climate, 26, 7372-7391, https://doi.org/10.1175/JCLI-D-12-00558.1, 2013.

McPeters, R. D., Bhartia, P. K., Haffner, D., Labow, G. J., and Flynn, L.: The version 8.6 SBUV ozone data record: An overview, J. Geophys. Res.-Atmos., 118, 8032-8039, https://doi.org/10.1002/jgrd.50597, 2013.

McPeters, R. D., Frith, S., and Labow, G. J.: OMI total column ozone: extending the long-term data record, Atmos. Meas. Tech., 8, 4845-4850, https://doi.org/10.5194/amt-8-4845-2015, 2015.

Molina, M. J. and Rowland, F. S.: Stratospheric sink for chlorofluoromethanes: chlorine atomc-atalysed destruction of ozone, Nature, 249, 810-812, https://doi.org/10.1038/249810a0, 1974.

Morgenstern, O., Hegglin, M. I., Rozanov, E., O’Connor, F. M., Abraham, N. L., Akiyoshi, H., Archibald, A. T., Bekki, S., Butchart, N., Chipperfield, M. P., Deushi, M., Dhomse, S. S., Garcia, R. R., Hardiman, S. C., Horowitz, L. W., Jöckel, P., Josse, B., Kinnison, D., Lin, M., Mancini, E., Manyin, M. E., Marchand, M., Marécal, V., Michou, M., Oman, L. D., Pitari, G., Plummer, D. A., Revell, L. E., Saint-Martin, D., Schofield, R., Stenke, A., Stone, K., Sudo, K., Tanaka, T. Y., Tilmes, S., Yamashita, Y., Yoshida, K., and Zeng, G.: Review of the global models used within phase 1 of the Chemistry-Climate Model Initiative (CCMI), Geosci. Model Dev., 10, 639-671, https://doi.org/10.5194/gmd-10-639-2017, 2017.

Nair, P. J., Froidevaux, L., Kuttippurath, J., Zawodny, J. M., Russell, J. M., Steinbrecht, W., Claude, H., Leblanc, T., van Gijsel, J. A. E., Johnson, B., Swart, D. P. J., Thomas, A., Querel, R., Wang, R., and Anderson, J.: Subtropical and midlatitude ozone trends in the stratosphere: Implications for recovery, J. Geophys. Res.-Atmos., 120, 7247-7257, https://doi.org/10.1002/2014JD022371, 2015.

NCAR: The Climate Data Guide: Multivariate ENSO Index, available at: https://climatedataguide.ucar.edu/climate-data/ multivariate-enso-index (last access: 11 May 2017), 2013.

Newman, P. A., Daniel, J. S., Waugh, D. W., and Nash, E. R.: A new formulation of equivalent effective stratospheric chlorine (EESC), Atmos. Chem. Phys., 7, 4537-4552, https://doi.org/10.5194/acp-7-4537-2007, 2007.

Nowack, P. J., Luke Abraham, N., Maycock, A. C., Braesicke, P., Gregory, J. M., Joshi, M. M., Osprey, A., and Pyle, J. A.: A large ozone-circulation feedback and its implications for global warming assessments, Nature Climate Change, 5, 41-45, https://doi.org/10.1038/nclimate2451, 2015.

Oman, L. D., Plummer, D. A., Waugh, D. W., Austin, J., Scinocca, J. F., Douglass, A. R., Salawitch, R. J., Canty, T., Akiyoshi, H., Bekki, S., Braesicke, P., Butchart, N., Chipperfield, M. P., Cugnet, D., Dhomse, S., Eyring, V., Frith, S., Hardiman, S. C., Kinnison, D. E., Lamarque, J.-F., Mancini, E., Marchand, M., Michou, M., Morgenstern, O., Nakamura, T., Nielsen, J. E., Olivié, D., Pitari, G., Pyle, J., Rozanov, E., Shepherd, T. G., Shibata, K., Stolarski, R. S., TeyssèDre, H., Tian, W., Yamashita, Y., and Ziemke, J. R.: Multimodel as- sessment of the factors driving stratospheric ozone evolution over the 21st century, J. Geophys. Res.-Atmos., 115, D24306, https://doi.org/10.1029/2010JD014362, 2010.

Oram, D. E., Ashfold, M. J., Laube, J. C., Gooch, L. J., Humphrey, S., Sturges, W. T., Leedham-Elvidge, E., Forster, G. L., Harris, N. R. P., Mead, M. I., Samah, A. A., Phang, S. M., Ou-Yang, C.-F., Lin, N.-H., Wang, J.-L., Baker, A. K., Brenninkmeijer, C. A. M., and Sherry, D.: A growing threat to the ozone layer from short-lived anthropogenic chlorocarbons, Atmos. Chem. Phys., 17, 11929-11941, https://doi.org/10.5194/acp-17-119292017, 2017.

Perliski, L. M., London, J., and Solomon, S.: On the interpretation of seasonal variations of stratospheric ozone, J. Geophys. Res., 37, 1527-1538, https://doi.org/10.1016/0032-0633(89)90143-8, 1989.

Randel, W. J. and Wu, F.: A stratospheric ozone profile data set for 1979-2005: Variability, trends, and comparisons with column ozone data, J. Geophys. Res.-Atmos., 112, D06313, https://doi.org/10.1029/2006JD007339, 2007.

Revell, L. E., Bodeker, G. E., Huck, P. E., Williamson, B. E., and Rozanov, E.: The sensitivity of stratospheric ozone changes through the 21 st century to $\mathrm{N}_{2} \mathrm{O}$ and $\mathrm{CH}_{4}$, Atmos. Chem. Phys., 12, 11309-11317, https://doi.org/10.5194/acp-12-113092012, 2012.

Rienecker, M. M., Suarez, M. J., Gelaro, R., Todling, R., Bacmeister, J., Liu, E., Bosilovich, M. G., Schubert, S. D., Takacs, L., Kim, G.-K., Bloom, S., Chen, J., Collins, D., Conaty, A., da Silva, A., Gu, W., Joiner, J., Koster, R. D., Lucchesi, R., Molod, A., Owens, T., Pawson, S., Pegion, P., Redder, C. R., Reichle, R., Robertson, F. R., Ruddick, A. G., Sienkiewicz, M., and Woollen, J.: MERRA: NASA's Modern-Era Retrospective Analysis for Research and Applications, J. Climate, 24, 3624-3648, https://doi.org/10.1175/JCLI-D-11-00015.1, 2011.

Santer, B. D., Wehner, M. F., Wigley, T. M. L., Sausen, R., Meehl, G. A., Taylor, K. E., Ammann, C., Arblaster, J., Washington, W. M., Boyle, J. S., and Brüggemann, W.: Contributions of Anthropogenic and Natural Forcing to Recent Tropopause Height Changes, Science, 301, 479-483, https://doi.org/10.1126/science.1084123, 2003.

Scarnato, B., Staehelin, J., Stübi, R., and Schill, H.: Long-term total ozone observations at Arosa (Switzerland) with Dobson and Brewer instruments (1988-2007), J. Geophys. Res.-Atmos., 115, D13306, https://doi.org/10.1029/2009JD011908, 2010.

Shepherd, T. G., Plummer, D. A., Scinocca, J. F., Hegglin, M. I., Fioletov, V. E., Reader, M. C., Remsberg, E., von Clarmann, T., and Wang, H. J.: Reconciliation of halogen-induced ozone loss with the total-column ozone record, Nat. Geosci., 7, 443-449, https://doi.org/10.1038/ngeo2155, 2014.

Sioris, C. E., McLinden, C. A., Fioletov, V. E., Adams, C., Zawodny, J. M., Bourassa, A. E., Roth, C. Z., and Degenstein, D. A.: Trend and variability in ozone in the tropical lower stratosphere over 2.5 solar cycles observed by SAGE II and OSIRIS, Atmos. Chem. Phys., 14, 3479-3496, https://doi.org/10.5194/acp-14-3479-2014, 2014.

Slaper, H., Velders, G. J. M., Daniel, J. S., de Gruijl, F. R., and van der Leun, J. C.: Estimates of ozone depletion and skin cancer incidence to examine the Vienna Convention achievements, Nature, 384, 256-258, https://doi.org/10.1038/384256a0, 1996. 
Sofieva, V. F., Kalakoski, N., Päivärinta, S.-M., Tamminen, J., Laine, M., and Froidevaux, L.: On sampling uncertainty of satellite ozone profile measurements, Atmos. Meas. Tech., 7, 18911900, https://doi.org/10.5194/amt-7-1891-2014, 2014.

Sofieva, V. F., Kyrölä, E., Laine, M., Tamminen, J., Degenstein, D., Bourassa, A., Roth, C., Zawada, D., Weber, M., Rozanov, A., Rahpoe, N., Stiller, G., Laeng, A., von Clarmann, T., Walker, K. A., Sheese, P., Hubert, D., van Roozendael, M., Zehner, C., Damadeo, R., Zawodny, J., Kramarova, N., and Bhartia, P. K.: Merged SAGE II, Ozone_cci and OMPS ozone profile dataset and evaluation of ozone trends in the stratosphere, Atmos. Chem. Phys., 17, 12533-12552, https://doi.org/10.5194/acp-17-125332017, 2017.

Solomon, S., Ivy, D. J., Kinnison, D., Mills, M. J., Neely, R. R., and Schmidt, A.: Emergence of healing in the Antarctic ozone layer, Science, 353, 269-274, https://doi.org/10.1126/science.aae0061, 2016.

Son, S.-W., Polvani, L. M., Waugh, D. W., Birner, T., Akiyoshi, H., Garcia, R. R., Gettelman, A., Plummer, D. A., and Rozanov, E.: The Impact of Stratospheric Ozone Recovery on Tropopause Height Trends, J. Climate, 22, 429-445, https://doi.org/10.1175/2008JCLI2215.1, 2009.

SPARC: SPARC CCMVal Report on the Evaluation of ChemistryClimate Models, edited by: Eyring, V., Shepherd, T., and Waugh, D., SPARC Report No. 5, WCRP-30/2010, WMO/TD No. 40, available at: http://www.sparc-climate.org/publications/ sparc-reports/sparc-report-no5/ (last access: 24 January 2018), 2010.

Steinbrecht, W., Claude, H., Köhler, U., and Hoinka, K. P.: Correlations between tropopause height and total ozone: Implications for long-term changes, J. Geophys. Res., 103, 19183-19192, https://doi.org/10.1029/98JD01929, 1998.

Steinbrecht, W., Froidevaux, L., Fuller, R., Wang, R., Anderson, J., Roth, C., Bourassa, A., Degenstein, D., Damadeo, R., Zawodny, J., Frith, S., McPeters, R., Bhartia, P., Wild, J., Long, C., Davis, S., Rosenlof, K., Sofieva, V., Walker, K., Rahpoe, N., Rozanov, A., Weber, M., Laeng, A., von Clarmann, T., Stiller, G., Kramarova, N., Godin-Beekmann, S., Leblanc, T., Querel, R., Swart, D., Boyd, I., Hocke, K., Kämpfer, N., Maillard Barras, E., Moreira, L., Nedoluha, G., Vigouroux, C., Blumenstock, T., Schneider, M., García, O., Jones, N., Mahieu, E., Smale, D., Kotkamp, M., Robinson, J., Petropavlovskikh, I., Harris, N., Hassler, B., Hubert, D., and Tummon, F.: An update on ozone profile trends for the period 2000 to 2016, Atmos. Chem. Phys., 17, 1067510690, https://doi.org/10.5194/acp-17-10675-2017, 2017.

Stenke, A., Schraner, M., Rozanov, E., Egorova, T., Luo, B., and Peter, T.: The SOCOL version 3.0 chemistry-climate model: description, evaluation, and implications from an advanced transport algorithm, Geosci. Model Dev., 6, 1407-1427, https://doi.org/10.5194/gmd-6-1407-2013, 2013.

Tegtmeier, S., Hegglin, M. I., Anderson, J., Bourassa, A., Brohede, S., Degenstein, D., Froidevaux, L., Fuller, R., Funke, B., Gille, J., Jones, A., Kasai, Y., Krüger, K., Kyrölä, E., Lingenfelser, G., Lumpe, J., Nardi, B., Neu, J., Pendlebury, D., Remsberg, E., Rozanov, A., Smith, L., Toohey, M., Urban, J., Clarmann, T., Walker, K. A., and Wang, R. H. J.: SPARC Data Initiative: A comparison of ozone climatologies from international satellite limb sounders, J. Geophys. Res.-Atmos., 118, 12229-12247, https://doi.org/10.1002/2013JD019877, 2013.
Thomason, L. W., Ernest, N., Millán, L., Rieger, L., Bourassa, A., Vernier, J.-P., Manney, G., Luo, B., Arfeuille, F., and Peter, T.: A global, space-based stratospheric aerosol climatology: 1979 to 2016, Earth Syst. Sci. Data Discuss., https://doi.org/10.5194/essd-2017-91, in review, 2017 (data available at: https://doi.org/10.5067/GloSSAC-L3-V1.0).

Tiao, G. C., Xu, D., Pedrick, J. H., Zhu, X., and Reinsel, G. C.: Effects of autocorrelation and temporal sampling schemes on estimates of trend and spatial correlation, J. Geophys. Res., 95, 20507-20517, https://doi.org/10.1029/JD095iD12p20507, 1990.

Tummon, F., Hassler, B., Harris, N. R. P., Staehelin, J., Steinbrecht, W., Anderson, J., Bodeker, G. E., Bourassa, A., Davis, S. M., Degenstein, D., Frith, S. M., Froidevaux, L., Kyrölä, E., Laine, M., Long, C., Penckwitt, A. A., Sioris, C. E., Rosenlof, K. H., Roth, C., Wang, H.-J., and Wild, J.: Intercomparison of vertically resolved merged satellite ozone data sets: interannual variability and long-term trends, Atmos. Chem. Phys., 15, 3021-3043, https://doi.org/10.5194/acp-15-3021-2015, 2015.

Varotsos, C., Cartalis, C., Vlamakis, A., Tzanis, C., and Keramitsoglou, I.: The Long-Term Coupling between Column Ozone and Tropopause Properties, J. Climate, $17, \quad 3843-3854$, https://doi.org/10.1175/15200442(2004)017<3843:TLCBCO>2.0.CO;2, 2004.

Vigouroux, C., Blumenstock, T., Coffey, M., Errera, Q., García, O., Jones, N. B., Hannigan, J. W., Hase, F., Liley, B., Mahieu, E., Mellqvist, J., Notholt, J., Palm, M., Persson, G., Schneider, M., Servais, C., Smale, D., Thölix, L., and De Mazière, M.: Trends of ozone total columns and vertical distribution from FTIR observations at eight NDACC stations around the globe, Atmos. Chem. Phys., 15, 2915-2933, https://doi.org/10.5194/acp15-2915-2015, 2015.

Weatherhead, E. C. and Andersen, S. B.: The search for signs of recovery of the ozone layer, Nature, 441, 39-45, https://doi.org/10.1038/nature04746, 2006.

Weber, M., Coldewey-Egbers, M., Fioletov, V. E., Frith, S. M., Wild, J. D., Burrows, J. P., Long, C. S., and Loyola, D.: Total ozone trends from 1979 to 2016 derived from five merged observational datasets - the emergence into ozone recovery, Atmos. Chem. Phys. Discuss., https://doi.org/10.5194/acp-2017-853, in review, 2017.

Wild, J. D. and Long, C. S.: A Coherent Ozone Profile Dataset from SBUV, SBUV/2: 1979 to 2016, in preparation, 2018.

WMO (World Meteorological Organization): Scientific Assessment of Ozone Depletion: 2006, Global Ozone Research and Monitoring Project - Report No. 50, 572 pp., Geneva, 2007.

WMO (World Meteorological Organization): Scientific Assessment of Ozone Depletion: 2010, Global Ozone Research and Monitoring Project-Report No. 52, 516 pp., Geneva, Switzerland, 2011.

WMO: Scientific Assessment of Ozone Depletion: 2014 Global Ozone Research and Monitoring Project Report, World Meteorological Organization,Geneva, Switzerland, p. 416, 2014.

WMO/NASA: International Ozone Trends Panel Report, Report, https://www.esrl.noaa.gov/csd/assessments/ozone/1988/report. html (last access: 24 January 2018), 1988.

Yu, P., Rosenlof, K. H., Liu, S., Telg, H., Thornberry, T. D., Rollins, A. W., Portmann, R. W., Bai, Z., Ray, E. A., Duan, Y., Pan, L. L., Toon, O. B., Bian, J., and Gao, R.-S.: Efficient transport of tropospheric aerosol into the stratosphere via the Asian summer 
monsoon anticyclone, P. Natl. Acad. Sci. USA, 114, 6972-6977, https://doi.org/10.1073/pnas.1701170114, 2017.

Ziemke, J. R., and Cooper, O. R.: Tropospheric ozone, in State of the Climate in 2016, B. Am. Meteorol. Soc., 98, S52-S54, 2017.
Ziemke, J. R., Chandra, S., Duncan, B. N., Froidevaux, L., Bhartia, P. K., Levelt, P. F., and Waters, J. W.: Tropospheric ozone determined from Aura OMI and MLS: Evaluation of measurements and comparison with the Global Modeling Initiative's Chemical Transport Model, J. Geophys. Res.-Atmos., 111, D19303, https://doi.org/10.1029/2006JD007089, 2006. 